\title{
*Winery wastes as precursors of sustainable porous carbons for environmental applications
}

Laura Guardia, Loreto Suárez, Nausika Querejeta, Covadonga Pevida,

\author{
Teresa A. Centeno ${ }^{1}$
}

Instituto Nacional del Carbón (INCAR-CSIC). Francisco Pintado Fe, 26. 33011 Oviedo (Spain)

\begin{abstract}
An efficient alternative for the management and valorization of the huge amount of seasonal wastes generated by winery industries is shown. Sustainable porous carbons were successfully prepared by one-pot activation of grape bagasse, stalks and oil free-seeds. Benefiting from the high moisture of these residues, a prior hydrothermal carbonization increases the activation yield and generates carbons with less oxygen content and inorganic impurities. The mild physical or chemical activation of winery wastes resulted in highly microporous carbons with specific surface $\mathrm{S}_{\mathrm{BET}}$ up to $2053 \mathrm{~m}^{2} / \mathrm{g}$ and great potential for environmental protection and electrical energy storage. They are excellent sorbents for $\mathrm{CO}_{2}$ capture under post- and precombustion conditions (16 and $69 \mathrm{wt} \%$, respectively) and achieve superior electrochemical capacitance of nearly $300 \mathrm{~F} / \mathrm{g}$ in aqueous electrolyte and $180 \mathrm{~F} / \mathrm{g}$ in ionic liquid basedmedium.
\end{abstract}

Keywords: Winery waste, activated carbon, hydrothermal carbonization, $\mathrm{CO}_{2}$ capture, supercapacitor

\footnotetext{
${ }^{1}$ Corresponding author

E-mail address: teresa@incar.csic.es (T.A. Centeno)
} 


\section{Introduction}

According to the recent report of the International Organization of Vine and Wine (OIV), wine production remains one of the most important agricultural activities in the world. In 2016, the area under vines rose to 7.5 mha worldwide and the production (excluding juice and musts) reached $267 \mathrm{mhl}$ (Aurand, 2015).

Winery activities generate huge amounts of seasonal wastes and their management is already becoming an acute problem of storage and elimination in both ecological and economic terms. It has been estimated that from $100 \mathrm{~kg}$ of grapes derive around $25 \mathrm{~kg}$ of residues, about $70 \%$ are grape skins, $12 \%$ of stalks and $18 \%$ of seeds (Toscano et al., 2013). Their high humidity and nutrients content provoke bacteria growth and uncontrolled emission of greenhouse gases. Landfilling is a great risk of spreading pests and diseases and the seeping down of alcohol and organic acids must also be prevented in order to avoid negative effects on soil and groundwater.

The traditional approach to revalue the grape marc by distillation has been much reduced due to the steady decline in the spirit beverages market in recent years. Moreover, this process also produces exhausted grape marc and harmful vinasse which require subsequent disposal (Zhang et al., 2017). Grape pomace may be also recovered in the form of animal feed but it needs a previous drying for storage. With regard to stalks and other residues with low economic value, landfilling in large dumps and incineration are the most commonly used processes for management.

In this context, winery industry is urging recycling alternatives to profit the wastes through their use as raw of added-value materials (Muhlack et al., 2017). Thus, a variety of technologies have been proposed to extract a great range of functional components such as natural antioxidants, biosurfactants, bioemulsifiers, ethanol, tartrates, citric acid, 
anthocyanins, polyphenols, dietary fiber, etc. from grape pomace (Arvanitoyannis et al., 2008; Devesa-Rey et al., 2011; Dwyer et al., 2014; Muhlack et al., 2017). Seeds separation from grape marc and subsequent extraction allows to obtain an oil highly appreciated in food and cosmetics markets (Dwyer et al., 2014; Toscano et al., 2013). Grape seed extracts with antioxidant activity also show potential as nutritional supplement for humans and animals (González-Paramás et al., 2004; O’Grady et al., 2008). However, these approaches still have to prove their profitable viability on a large scale (Dwyer et al., 2014) and, as far as they recover only part of the components, share many of the disposal concerns of the raw wastes. Much attention is also being paid to winery wastes for their richness in compounds of great interest for soil fertility (Arvanitoyannis et al., 2008; Muhlack et al., 2017) although the presence of certain polyphenols with phytotoxic and antimicrobial effects may hinder their direct use (Bustamante et al., 2008). In recent years composting and anaerobic digestion are being implemented to obtain soil conditioners and high-grade organic fertilizers (Arvanitoyannis et al., 2008; Devesa-Rey et al., 2011; Muhlack et al., 2017; Zhang et al., 2017) and biogas (El Achkar et al., 2016).

The growing interest in obtaining energy from biomass has stimulated studies on the possibilities for the disposal of winery wastes by thermal decomposition. Combustion is an effective mean to reduce the total amount of residues (Muhlack et al., 2017; Zhang et al., 2017). It has been estimated that the potential energy content of the residual biomass from a hectare of grapevine is around 19 GJ of gross energy although the high content of water and ashes of these by-products critically reduce the combustion efficiency (Toscano et al., 2013). The detailed analysis by Zhang et al. (2017) revealed that pyrolysis is more economically viable than combustion and exhibits a great minimisation of residues by producing $151 \mathrm{~kg}$ of biochar and $140 \mathrm{~kg}$ of biofuel per tonne of grape marc. 
The humidity of the winery wastes is a disadvantage to their transport and clearly detrimental to the energetic efficiency of their thermochemical processing. Therefore, alternatives compatible with the presence of water such as hydrothermal carbonization (HTC) result really interesting. The strength of this technology relies precisely in the transformation of wet feedstocks without the drying pre-treatment of traditional approaches. Requiring milder operation conditions (generally $180-250^{\circ} \mathrm{C}$ and $20-40$ bar) with respect to the other treatments (Kambo and Dutta, 2015), HTC presents a more affordable technical applicability. The products are primarily a solid phase enriched in carbon (hydrochar), a liquid phase with dissolved organic compounds and a small quantity of gases (Kambo and Dutta, 2015). Pala et al. (2014) have found higher energy densification and energy yield by HTC of grape pomace than by torrefaction whereas the aqueous phase displayed antioxidant activity. More recent studies support hydrothermal treatment of grape marc as an efficient pathway for producing $\mathrm{CO}_{2}$ neutral solid fuels on-site at the wineries (Lucian and Fiori, 2017; Mäkelä et al., 2017). Along with obtaining fuels, several high-valuable chemicals were also found in the aqueous phase. Yedro et al. (2015) reported the successful extraction of polyphenols and the production of oil, pentose and hexose sugars as well as lignin from grape seeds by HTC. The current expansion of applications of porous carbons (Titirici et al., 2015) has encouraged research on low-cost sustainable materials. The elimination of winery wastes and above all the production of carbons with the highest performance from them would imply a significant advance by the transformation of a problem into a great advantage.

A literature review reveals a lack of systematic studies on carbons from winery solid wastes. Most data reported on carbons from grape residues are part of comprehensive studies to evaluate the overall potential of biomass as precursor of porous carbons. As summarized in Table 1, the majority of grapes based-carbons are produced by multi-step processing of some 
component (mostly seeds) and their application is essentially focused to the removal of pollutants from aqueous streams.

The interest of the present systematic approach concentrates in highlighting the potential of each single waste: bagasse, stalks and the residue from the mechanical extraction of seeds oil. Firstly, the simplicity of the hydrothermal carbonization for the generation of carbon-enriched materials raises the possibility of using this technology for minimizing the polluting impact of the winery solid residues. Secondly, the success of a simple one-step activation by $\mathrm{CO}_{2}$ or $\mathrm{KOH}$ provides a second chance to these feedstocks by means of advanced environmental applications such as $\mathrm{CO}_{2}$ capture and supercapacitors.

Despite their different origin and structure, the present solid wastes generated in wine production closely resemble with respect to hydrothermal carbonization and activation, thus allowing their management, stabilization and valorization all together, without a significant effect on the final product.

\section{Materials and Methods}

\subsection{Raw materials}

Three different wastes generated in local wineries at the Northwest of Spain have been studied: i) bagasse made of skins and seeds (B), ii) stalks (R) and iii) defatted-seeds (S). The latter were supplied as small cylindrical monoliths resulting from seeds extrusion to extract oil.

\subsection{Synthesis of hydrochars}

The bagasse and the stalks were used as received while oil free-seed monoliths were milled to a particle size $\leq 1 \mathrm{~mm}$ prior to the experiments. $10 \mathrm{~g}$ of residues were subjected to hydrothermal carbonization at $200{ }^{\circ} \mathrm{C}$ in the presence of $10 \mathrm{~g}$ of water in a Teflon liner 
stainless steel autoclave under autogenous pressure for 12 hours. The solid product was filtered, washed with $100 \mathrm{ml}$ of water and dried at $100{ }^{\circ} \mathrm{C}$ for $24 \mathrm{~h}$. The resulting hydrochars were named using $\mathrm{H}$ after the corresponding raw precursor acronym ( $\mathrm{BH}, \mathrm{RH}$ and $\mathrm{SH})$.

\subsection{Synthesis of porous carbons}

\subsubsection{Physical activation}

Samples (previously dried and ground below $1 \mathrm{~mm}$ ) were placed in a double-jacket quartz reactor and, heat treated in $\mathrm{CO}_{2}(370 \mathrm{ml} / \mathrm{min})$ up to $800^{\circ} \mathrm{C}$ during $30 \mathrm{~min}$. The heating rate was $5{ }^{\circ} \mathrm{C} / \mathrm{min}$. The resulting materials are denoted as $\mathrm{X}(\mathrm{H}) \mathrm{AC}$ where $\mathrm{X}$ refers to the feedstock and $\mathrm{H}$ applies to the respective hydrochar.

\subsubsection{Chemical activation}

Samples were thoroughly ground with $\mathrm{KOH}(\mathrm{KOH} / \mathrm{sample}=2$, by weight $)$ and heated at $5^{\circ} \mathrm{C} / \mathrm{min}$ up to $800{ }^{\circ} \mathrm{C}$ under $\mathrm{N}_{2}(72 \mathrm{ml} / \mathrm{min})$ and held for $1 \mathrm{~h}$. The solids were washed with $\mathrm{HCl}(10 \mathrm{wt} \%)$ to remove any inorganic salt and with boiling distilled water until conductivity less than $2 \mu \mathrm{S}^{-1}$. Finally, they were dried in an air oven at $100{ }^{\circ} \mathrm{C}$ for $24 \mathrm{~h}$. The obtained carbons are designated as $\mathrm{X}(\mathrm{H}) \mathrm{AK}, \mathrm{X}$ referring to the feedstock and $\mathrm{H}$ applying to the respective hydrochar.

\subsection{Materials characterization}

The assessment of the biochemical composition of the different feedstocks involved a previous treatment of the samples sized to $250-500 \mu \mathrm{m}$ in a Soxhlet extractor with acetone for $8 \mathrm{~h}$ and, subsequently, with distilled water for $4 \mathrm{~h}$. The resulting free extractive-biomass was dried in air at $60{ }^{\circ} \mathrm{C}$ to a moisture content below $15 \%$. The contents of lignin and cellulose were determined following TAPPI standard methods, respectively, T222om-02 and T212om02. The Browning Method (Schuerch, 1968) was used for holocellulose assessment. The 
amount of hemicellulose was estimated from the difference between the contents of holocellulose and cellulose (Pettersen, 1984).

The morphology of the samples was examined by Scanning Electron Microscopy (SEM) using a Carl Zeiss DMS-942 microscope.

The chemical characteristics of the diverse materials were determined by different techniques. Thermogravimetric runs (Setaram TGA24) at $100{ }^{\circ} \mathrm{C}$ in air flow provided the moisture of the different samples. Subsequent treatment up to $815^{\circ} \mathrm{C}$ for $30 \mathrm{~min}$ reported their ash content. Elemental analysis was carried out in a LECO CHNS-932 microanalyser provided with a LECO VTF-900 accessory for oxygen. Temperature programmed desorption (TPD) analysis entailed sample heating from 20 to $1000{ }^{\circ} \mathrm{C}$ at $15{ }^{\circ} \mathrm{C} / \mathrm{min}$ under $50 \mathrm{~cm}^{3} / \mathrm{min}$ Ar flow (Setaram TGA92 coupled to mass spectrometer OmnistarTM-Pfeiffer Vacuum). TPD curves were fitted with GaussianAmp peaks and the evolution of $\mathrm{CO}$ and $\mathrm{CO}_{2}$ was semi-quantitatively determined using calcium oxalate as standard.

Textural features of the carbons were obtained by physical adsorption of $\mathrm{N}_{2}$ at $77 \mathrm{~K}$ (Micromeritics ASAP 2010) and $\mathrm{CO}_{2}$ at $273 \mathrm{~K}$ (Micromeritics TriStar 3000). "Although the limited validity of the BET equation for the characterization of microporous adsorbents has been widely addressed (Centeno and Stoeckli, 2010; ISO [International Organization for Standardization], 2010; Thommes et al., 2015; Tian and Wu, 2018), it is still the most widely used approach for determining the specific surface area of porous carbons. In a first approximation, the $\mathrm{N}_{2}$ isotherm was analyzed by this method following the recommendations of Rouquérol et al. (Rouquerol et al., 2007) and the equivalent BET-surface area $\left(\mathrm{S}_{\mathrm{BET}}\right)$ is included exclusively for comparison purposes". 
The systematic analysis of $\mathrm{N}_{2}$ isotherms by the simultaneous use of several approaches including QSDFT model (Quantachrome software package), Kaneko’s comparison plot and Dubinin's theory allowed to get more reliable information on the specific surface area $\left(\mathrm{S}_{\mathrm{N} 2}\right)$ and other various porosity features (total pore volume $\left(\mathrm{V}_{\text {pores }}\right)$, micropore volume $\left(\mathrm{W}_{\mathrm{o}-\mathrm{N} 2}\right)$ and average micropore width $\left(\mathrm{L}_{\mathrm{o}-\mathrm{N} 2}\right)$ (Centeno and Stoeckli, 2010). Complementary information on the ultramicroporosity $\left(\mathrm{S}_{\mathrm{CO} 2}, \mathrm{~W}_{\mathrm{o}-\mathrm{CO} 2}, \mathrm{~L}_{\mathrm{o}-\mathrm{CO} 2}\right)$ was obtained by the analysis of $\mathrm{CO}_{2}$ isotherm by the NLDFT approach and the Dubinin-Raduskevich equation. The pore size distributions (PSD) were obtained from the NLDFT-analysis of $\mathrm{CO}_{2}$ isotherm combined with the QSDFTdata from $\mathrm{N}_{2}$ adsorption.

\subsection{Applications of the activated carbons}

\subsubsection{Adsorbents for $\mathrm{CO}_{2}$ capture}

The Dubinin's theory allowed the calculation of the theoretical equilibrium $\mathrm{CO}_{2}$ uptakes under post- and pre-combustion conditions (1 and 20 atm, respectively, and $298 \mathrm{~K}$ ) using the characteristic energy $\left(\mathrm{E}_{\mathrm{o}}\right)$ and the micropore volume $\left(\mathrm{W}_{\mathrm{o}}\right)$ obtained from the analysis of $\mathrm{CO}_{2}$ and $\mathrm{N}_{2}$ adsorption isotherms (Martín et al., 2010). For some selected carbons, $\mathrm{CO}_{2}$ capture capacities at both the atmospheric (Setaram TGA2) and high (magnetic suspension balance Rubotherm-VTI) pressures were experimentally confirmed by the maximum mass increase of the sample when exposed to a pure $\mathrm{CO}_{2}$ atmosphere.

\subsubsection{Supercapacitor electrodes}

Two electrodes separated by a glassy fibrous material (Wathman 934-AH) were assembled in a Swagelok cell (8 $\mathrm{mm}$ in diameter). The system was subjected to galvanostatic chargingdischarging cycles at $1 \mathrm{~mA} / \mathrm{cm}^{2}$ (Autolab-Ecochimie PGSTAT 30), the voltage ranging from 0 to $1 \mathrm{~V}$ in the aqueous $2 \mathrm{M} \mathrm{H}_{2} \mathrm{SO}_{4}$ electrolyte and between 0 and $3.5 \mathrm{~V}$ in the ionic liquid 1- 
Ethyl-3-methylimidazolium bis(trifluoromethylsulfonyl)imide dissolved in acetonitrile (weight ratio 1:1, EMImBF 4 /AN). The electrodes consisted of $90 \mathrm{wt} . \%$ of carbon, $5 \mathrm{wt} . \%$ of polytetrafluoroethylene (PTFE) and 5 wt.\% of carbon black.

The gravimetric capacitance was calculated according to $\mathrm{C}=2 \mathrm{I} / \mathrm{m}(\mathrm{dV} / \mathrm{dt})$ where $\mathrm{I}$ is the current, $\mathrm{dV} / \mathrm{dt}$ is the slope of the discharge curve and $\mathrm{m}$ is the mass of carbon in one electrode. Therefore, all capacitance values refer to a single electrode.

\section{Results and discussion}

\subsection{Characteristics of the winery wastes}

As reported by Table 2, the present feedstocks (bagasse, stalks and oil free-seeds) are composed of the three primary fractions of lignocellulosic materials (Kambo and Dutta, 2015). The content of cellulose ranges between 10 and $17 \mathrm{wt} . \%$. The stiff cellulose fibrils are hold by 12-24 wt.\% of hemicellulose. The presence of 33-40 wt.\% of lignin retains all components strongly intermeshed. There is no statistically significant difference in the biopolymer percentages of oil free-seeds and bagasse whereas the lignin/saccharides ratio in stalks $(1.8)$ is double than in the other wastes $(\sim 0.9)$.

These biomass residues also include $23-33$ wt. $\%$ of a variety of non-structural sugars, proteins, waxes, etc. soluble in water and ethanol (extractives) and a low amount of inorganic compounds. The latter accounts for $6 \mathrm{wt} . \%$ in the current bagasse and stalks although it may depend on the contamination during harvesting. Oil free-seeds display somewhat higher purity with around 3 wt.\% of ashes.

The set of winery feedstocks displays a similar elemental composition (Table 3) which also fits into the standard values for biomass (Gollakota et al., 2016). 
The comparable profiles of $\mathrm{CO}_{2}$ and $\mathrm{CO}$ release in TPD experiments (Fig. 1) suggest that the chemical nature of the surface is virtually the same for all wastes. Thus, the two peaks dominating the $\mathrm{CO}_{2}$ evolution at around $360{ }^{\circ} \mathrm{C}$ and $650{ }^{\circ} \mathrm{C}$ are indicative of weak acidic carboxylic- and lactones-groups, respectively (Zielke et al., 1996). The temperatures at which a remarkable $\mathrm{CO}$ release occurs reveal the presence of $\alpha$-substituted ketones and/or aldehydes $\left(\sim 350{ }^{\circ} \mathrm{C}\right)$, phenolic groups $\left(670-700{ }^{\circ} \mathrm{C}\right)$ and chromenes and pyrones $\left(980-1050{ }^{\circ} \mathrm{C}\right)$ (Figueiredo et al., 2007). The additional peak centered at $830{ }^{\circ} \mathrm{C}$ corresponds to carbonyl and/or quinones in the oil free-seeds surface (Figueiredo et al., 2007). The integration of the TPD curves reports somewhat lower content of surface oxygenated-functionalities in oil-free seeds (Table 3).

\subsection{Features of the hydrochars}

Taking advantage of the high humidity of bagasse and stalks, a mild hydrothermal carbonization at $200{ }^{\circ} \mathrm{C}$ results really attractive for their management. Both wastes are available with a moisture of around $60 \mathrm{wt} . \%$, which means that they contain around 1.5 times the amount of water (by weight) with respect to dry material. The penalty is not so relevant for oil-free seeds with a humidity of around $10 \mathrm{wt} . \%$.

Without prior energy consumption, the HTC processing of the winery residues minimizes the polluting impact of their rapid degradation in air by stabilizing them in partially carbonized products. Table 3 shows that the carbon content is increased up to around 67\% (on a dry-ashfree basis (d.a.f.)) from $47-55 \%$ of the raw biomass whereas oxygen content is decreased by $35-40 \%$.

The evolution of the atomic $\mathrm{H} / \mathrm{C}$ and $\mathrm{O} / \mathrm{C}$ ratios in a Van Krevelen diagram (Van Krevelen, 1950) indicates that hydrothermal treatment results in dehydration and decarboxylation 
reactions via the removal of low molecular weight compounds (Fig. 2). These variations are consistent with the formation of a well-condensed structure observed for other hydrochars (Wiedner et al., 2013).

In view of the similar bio-composition of oil free-seeds and bagasse (Table 2), their HTC processing was expected to provide comparable yields. However, it results more efficient for the former since $72 \%$ of SH is obtained whereas $\mathrm{BH}$ accounts for $54 \%$ of the raw bagasse. On the other hand, the higher lignin/saccharides ratio in stalks has not impact and the yield remains at around $57 \%$ for $\mathrm{RH}$. The lack of a direct correspondence with the basic trend found for the HTC throwput of the single components, lignin > cellulose > hemicellulose, suggests that interactions between biopolymers take place (Kang et al., 2012).

The mild hydrothermal carbonization is an effective way to increase the turnover time of the carbon contained in the winery residues. The $\mathrm{C}$ recovery is $89 \%$ for the oil free-seeds, $79 \%$ for the stalks and $70 \%$ for the bagasse. For comparison, the biochar obtained by hightemperature pyrolysis $\left(\sim 600^{\circ} \mathrm{C}\right)$ of oil free-seeds retains only $50 \%$ of the initial carbon content.

The ability of HTC to transfer water-soluble inorganic components of the biomass to the liquid phase is an additional advantage of this technology. As observed in Table 3 , hydrothermal treatment applied on the three winery wastes leads to carbon enriched-materials with only about $3 \%$ of ash. This is not possible in the case of dry carbonization, the percentage being as high as $7 \%$ in the biochar resulting from oil free-seeds at $600{ }^{\circ} \mathrm{C}$. Such a reduction in ash content would become highly advantageous for further applications of the materials. 
With the exception of additional peroxide- and carbonyl/quinones-groups in SH (as indicated by, respectively, $\mathrm{CO}_{2}$ desorption at around $550{ }^{\circ} \mathrm{C}$ and $\mathrm{CO}$ release at $810{ }^{\circ} \mathrm{C}$ ), the deconvolution of the TPD profiles suggests quite similar functionalities in the surface of the hydrochars to those detected in the initial biomass. The $\mathrm{CO}_{2}$ evolution (Fig. 1) reports that weak acidic carboxylic and lactones groups still remain after HTC although the amount is somewhat reduced (Table 3). Additionally, the shifting of the peaks towards slightly higher temperatures reveals the formation of more stable bonds and changes in the electronic environment of the surface groups already existing in the feedstocks. Such effect is more remarkable for the O-functionalities desorbing as $\mathrm{CO}$. The increase in their total amount (Table 3) likely indicates that the removal of $\mathrm{CO}_{2}$ may also involve secondary reactions originating surface complex (C[O]) and free $\mathrm{CO}$ (Figueiredo et al., 2007).

SEM images (Fig. 3) evidence that structural scaffolds of the winery residues are mostly preserved by HTC. The hydrochars particles virtually maintain the original cell morphology although with less defined shape as a consequence of volatiles release. The presence of microspheres, so characteristic in saccharides derived-hydrochars (Jain et al., 2016), is observed in the bagasse-hydrochar but hardly detected in those from the other feedstocks. Very likely, they are mostly generated from the sugars left after the must extraction. Hemicellulose may also contribute somewhat to the generation of globular carbon items since its decomposition starts at $\sim 175^{\circ} \mathrm{C}$. A relevant contribution from the more polymerized cellulose, which degrades above $220-250{ }^{\circ} \mathrm{C}$, is practically excluded (Donar et al., 2016; Pala et al., 2014).

Hydrochars from winery residues present no relevant porosity accessible to $\mathrm{N}_{2}$ at $77 \mathrm{~K}$ (Fig. $\mathrm{S} 1)$ and the $\mathrm{S}_{\mathrm{N} 2}$ of around $24 \mathrm{~m}^{2} / \mathrm{g}$ for $\mathrm{BH}$ and $\mathrm{RH}$ and $9 \mathrm{~m}^{2} / \mathrm{g}$ of the seeds-hydrochar correspond to the typical low values reported for similar materials (Jain et al., 2016). 
However, the complementary use of $\mathrm{CO}_{2}$ adsorption at $273 \mathrm{~K}$ (Fig. S1) reveals a structure formed by ultramicropores with size < 0.8-0.9 nm (Lozano-Castelló et al., 2004) which leads to $\mathrm{S}_{\mathrm{CO} 2}$ of 204,98 and $64 \mathrm{~m}^{2} / \mathrm{g}$ for $\mathrm{BH}, \mathrm{RH}$ and $\mathrm{SH}$, respectively.

In summary, despite their different origin and structure, all present feedstocks closely resemble with respect to hydrothermal carbonization, thus allowing their management and stabilization all together, without a significant effect on the final product.

\subsection{Characteristics of the activated carbons}

The combination of diverse techniques leads to some general patterns for the activation of winery wastes. Table 3 illustrates the activation impact on the chemical composition, a significant increase in carbon content above $84 \%$ accompanied by a drop in oxygen to values between 5 and $14 \mathrm{wt} . \%$ taking place. The process generates a highly condensed chemical structure (Fig. 2), notably reduced in surface oxygenated groups (Table 3). It is noteworthy the similarity of the surface chemistry of all activated carbons, mainly consisting of carboxylic-, lactone- and carbonyl/quinone-groups. Pyrone and chromene-functionalities are also present in $\mathrm{CO}_{2}$-activated carbons (Table $\mathrm{S} 1$ ).

Regardless of the precursor and activating agent, $\mathrm{N}_{2}$ adsorption isotherms are type I (Fig. S2), indicative of an essentially microporous network. The pore size distributions (PSD) confirm a major contribution from pores below $1 \mathrm{~nm}$ (Fig. 4).

In spite of some common features, a more detailed study shows remarkable distinctions between the sets synthesised by physical or chemical activation.

\subsubsection{Physical activation}

The simple heating of dry bagasse and oil-free seeds in $\mathrm{CO}_{2}$ at $800{ }^{\circ} \mathrm{C}$ for only $30 \mathrm{~min}$ maintains the cellular structure (Fig. 3) while generating porous carbons with extremely 
narrow PSDs (Fig. 4). In spite of the limited porous volume (Fig. S2), such network development is virtually dominated by ultramicropores of $0.53-0.60 \mathrm{~nm}$ in average size (Table 4) and results in surface areas $\mathrm{S}_{\mathrm{CO} 2}$ as high as $979 \mathrm{~m}^{2} / \mathrm{g}$ for BAC and $819 \mathrm{~m}^{2} / \mathrm{g}$ for SAC. In the present case, $\mathrm{S}_{\mathrm{BET}}$ (which reflects the area equivalent to the total volume adsorbed) is misleading as the remarkable presence of pores below $0.8 \mathrm{~nm}$ causes the BET method to underrate the total surface area (Centeno and Stoeckli, 2010). The fact that the actual surface area $\mathrm{S}_{\mathrm{N} 2}$, estimated by the combination of different methods (Centeno and Stoeckli, 2010) is smaller than $\mathrm{S}_{\mathrm{CO} 2}$, reflects the difficulties of $\mathrm{N}_{2}$ at $77 \mathrm{~K}$ to access to the extremely small porosity (Lozano-Castelló et al., 2004). Anyway, the comparison with values of Table 1 shows that the present one-pot activation by $\mathrm{CO}_{2}$ competes favorably with other multi-stage physical activation previously used on winery wastes.

Contrary to the success with bagasse and seeds, the direct physical activation clearly fails on stalks. The yield of the process is only $9 \mathrm{wt} \%$ and $42.4 \mathrm{wt} \%$ of the resulting material corresponds to ashes. It appears that the higher proportion of lignin in the intracellular matrix of stalks acts as a protective barrier and the particles are burned instead of activated (Suhas et al., 2007). In fact, the resulting RAC is mainly formed by fibers with a specific surface limited to $\sim 200 \mathrm{~m}^{2} / \mathrm{g}$.

Taking into account the relevance of the materials purity for advanced applications, physical activation would require a subsequent acid-treatment. As illustrated by Table 3, only the material derived from oil free-seeds with $9 \mathrm{wt} \%$ of ash would achieve an actual potential while $17 \mathrm{wt} \%$ in the bagasse-activated carbon restricts its direct use in some fields. On this regard, the partial solubilization of the inorganic components that takes place during HTC becomes highly advantageous for subsequent physical activation. 
Thus, a prior hydrothermal treatment on oil-free seeds successfully leads to an activated carbon (SHAC) with 50\% less impurities (Table 3) and 20\% higher surface (Table 4). In the case of bagasse, the pre-HTC has a major effect on the reduction of impurities to $6.5 \%$ in BHAC. The slight decrease in both the volume $\mathrm{W}_{\mathrm{o}-\mathrm{CO} 2}$ and the average micropores size $\mathrm{L}_{\mathrm{O}-\mathrm{CO} 2}$ only affect the total surface $\mathrm{S}_{\mathrm{CO} 2}$ by $-7 \%$ with respect to $\mathrm{BAC}$ obtained without previous HTC.

HTC results to be an indispensable step for producing porous carbons from stalks. The poor result obtained by their direct activation with $\mathrm{CO}_{2}$ is notably overcome by using the corresponding hydrochar as precursor and an ultramicroporous activated carbon with $635 \mathrm{~m}^{2} / \mathrm{g}$ and $5.2 \%$ of ash is obtained. The hydrothermal treatment weakens the cellular matrix of the feedstock (Islam et al., 2015; Sabio et al., 2016) facilitating subsequent diffusion of the gaseous activating agent.

The effectiveness of a previous HTC goes even further by increasing the activation yield (Fig. 5) and, simultaneously, reducing significantly the oxygen functionalities (Table 3) in the $\mathrm{CO}_{2}$ activated carbons. No significant effect on the total surface area $\mathrm{S}_{\mathrm{CO} 2}$ is detected although the relevant reduction in $S_{\mathrm{N} 2}$ indicates a less accessible porous network of the materials from hydrochar.

\subsubsection{Chemical activation}

Winery wastes have proved to be very versatile precursors that allow obtaining a wide spectrum of porous carbons by simply selecting the activation conditions. Thus, Fig. 5, as an indicator of the effectiveness of the different treatments on winery wastes, illustrates relevant differences between the materials obtained by the physical and chemical processes while the role of the feedstock is much more limited. 
Definitely, treatment with $\mathrm{KOH}$ generates an extraordinary development of porosity in all winery wastes, making it possible for stalks to generate porous carbons very similar to those from the other residues (Tables 3 and 4). Regardless of the feedstock, the carbon particles obtained with $\mathrm{KOH}$ exhibit a typical morphology characterized by a fluffly appearance with no trace of the initial cellular network (Fig. 3).

It is noteworthy that whereas the activation with $\mathrm{CO}_{2}$ engenders pores mainly below $0.6 \mathrm{~nm}$, $\mathrm{KOH}$-materials also exhibit a noticeable contribution from larger pores up to $1.4 \mathrm{~nm}$. Despite being $\mathrm{KOH}$ a harsh activating agent, the set SAK, BAK and RAK still remain entirely microporous (Fig. 4) and total pore volumes of $0.70-0.83 \mathrm{~cm}^{3} / \mathrm{g}$ (Table 4) translate to $\mathrm{S}_{\mathrm{BET}}$ as high as $1700-2050 \mathrm{~m}^{2} / \mathrm{g}$ which exceeds the values obtained by other multi-step chemical activation processes on winery residues (Table 1). Regarding the high values of $\mathrm{S}_{\mathrm{BET}}$ frequently found in highly activated carbons, it should be taken into account that it does not actually correspond to their specific surface area. The quantitative correlation found by Centeno et al. (Centeno and Stoeckli, 2010) between the actual surface $S_{\text {total }}, S_{\text {BET }}$ and the average micropore width $\mathrm{L}_{\mathrm{o}}, \mathrm{S}_{\text {total }}=\mathrm{S}_{\mathrm{BET}} /\left(1.2 \times \mathrm{L}_{\mathrm{o}}\right)$, shows that $\mathrm{S}_{\mathrm{BET}}$ provides a reliable estimate of the total surface area of carbons with micropores around $0.9-1.1 \mathrm{~nm}$ but it overestimates the real surface for carbons with a high proportion of pores wider than $1.1 \mathrm{~nm}$.

Anyway, the comprehensive textural characterization by different methods (see section 2.4) confirms the outstanding porosity of the present chemically activated carbons. Their surface area $S_{\mathrm{N} 2}$ is around $1300-1500 \mathrm{~m}^{2} / \mathrm{g}$ (Table 4) which approaches the highest limits of actual surface found for activated carbons (Lobato et al., 2017). In addition, the good agreement with $\mathrm{S}_{\mathrm{CO} 2}$ indicates that $\mathrm{KOH}$ activation also enhances the accessibility of the porous system of the resulting activated carbons (Fig. 4). 
Regarding the surface nature, there are no remarkable differences in the density of surface [O]-groups in the $\mathrm{KOH}$-activated carbons derived from $\mathrm{S}$ and $\mathrm{B}$ if compared to their homologues obtained with $\mathrm{CO}_{2}$ (Table 3) although TPD profiles reveal higher stability of COfunctionalities (Fig. 2).

A very positive result of chemical activation is the low ash content of the carbons SAK, BAK and RAK (2-4 wt\%). These values can be further reduced by a previous hydrothermal treatment, the impurities accounting for only $0.1 \mathrm{wt} . \%$ in BHAK (Table 3).

Fig. 5 shows how the severity of the chemical activation minimizes the influence of a prior hydrothermal carbonization. The impact of pre-HTC on the $\mathrm{KOH}$-activation yield as well as on the composition of the resulting materials (Table 3), is much less obvious than that observed on physical activation. These findings are coherent with the similar morphology and texture of their counterparts with no pre-treatment. The particles of SHAK, BHAK and RHAK display the typical sponge-like morphology observed for SAK, BAK and RHAK, obtained directly from the dry feedstocks (Fig. 3). The total surface area of the $\mathrm{KOH}$-activated hydrochars is $15-20 \%$ higher (Fig. 5), the PSD being barely modified (Fig. 4).

\subsection{Applications}

The variety of physico-chemical features of the present carbons opens their possibilities for diverse applications with high environmental impact.

\subsection{1 $\mathrm{CO}_{2}$ capture capacity}

As shown below, winery wastes allow the preparation of low-cost carbon adsorbents with superior $\mathrm{CO}_{2}$ capture in thermoelectric power plants. Following Martín et al. (2010), the suitability of the present carbons to be applied as adsorbent for $\mathrm{CO}_{2}$ capture has been estimated. Table 5 summarizes their maximum $\mathrm{CO}_{2}$ uptake at 1 and $20 \mathrm{~atm}(298 \mathrm{~K})$, i.e. under 
conditions relevant to post- and pre-combustion capture, respectively. It also includes experimental results for selected samples which confirm the accuracy of this approach.

Despite the simplicity of the one-step physical activation, the resulting materials reach postcombustion $\mathrm{CO}_{2}$ capture of around 10-12 wt \% which meet the upper-bound reported in the literature for standard activated carbons (Lee and Park, 2015; Marco-Lozar et al., 2014; Martín et al., 2010). Although they display moderate pore volumes, the ability is enhanced by their tailored porosity virtually made of pores smaller than $0.6 \mathrm{~nm}$ (Fig. 4).

Higher pore volumes and a wider distribution of micropores achieved by activation with $\mathrm{KOH}$ cause the resulting materials to surpass these values (13-16 wt\%), while also being excellent for capture under pre-combustion conditions (55-69 wt\%) (Marco-Lozar et al., 2014).

\subsubsection{Electrochemical capacitance as electrodes in supercapacitors}

Activated carbons derived from winery wastes are also worthy of attention as electrode materials for the storage of electrical energy in supercapacitors (Fig. 6). Taking advantage of the high specific surface area of the materials obtained by mild $\mathrm{KOH}$ activation, their electrochemical capacitance is among the highest reported for porous carbons (Lobato et al., 2017). The as-prepared materials exhibit superior specific capacitance of $262-296 \mathrm{~F} / \mathrm{g}$ in the aqueous $\mathrm{H}_{2} \mathrm{SO}_{4}$. Furthermore, they also offer advantages with respect to attainable specific capacitance ranging between 142 and $179 \mathrm{~F} / \mathrm{g}$ (Table 5) in the advanced electrolyte based on the ionic liquid $\mathrm{EMImBF}_{4}$ (Bhoyate et al., 2017; Zhang and Zhao, 2012).

As a consequence of their attainable electrochemical capacitance, high availability, low economic value and environmental concern, they offer advantages with respect to other biomass based-carbons or more sophisticated materials. 


\section{Conclusions}

This study supports the option to value solid winery wastes via one-pot activations. Bagasse, stalks and oil free-seeds have resulted excellent precursors for the production of low-cost sustainable porous carbons with promising commercial prospects. The particular physicochemical features of the resulting activated carbons provided with high performance for environmental applications such as $\mathrm{CO}_{2}$ capture processes and storage of electrical energy in supercapacitors.

Benefiting from the high humidity of the winery wastes, a mild hydrothermal carbonization resulted to be an interesting technology which minimizes the polluting impact by stabilizing them in enriched-carbon solids products and acts as a leaching process.

\section{Aknowledgements}

This study received financial support from CSIC in the frame of Project PIE-201680E035. N.Q. acknowledges a fellowship from Gobierno del Principado de Asturias (Programa Severo Ochoa). L.S. thanks the support from Programa Estatal de Promoción del Talento y su Empleabilidad en I+D+i and European Social Fund-Youth Employment Initiative.

The selfless support and winery wastes provided by Mr. Víctor Alejandro Chacón (Bodega Chacón Buelta-Cerredo, Spain), Dr. M. Carmen Martínez (MBG-CSIC) and Mr. Carlos Ron (Bodega Vitheras-Carballo, Spain) are specially acknowledged. The authors wish to thank for supplying grape bagasse and stalks.

\section{References}

Al Bahri, M., Calvo, L., Gilarranz, M.A., Rodriguez, J.J., 2016. Diuron Multilayer Adsorption on Activated Carbon from $\mathrm{CO}_{2}$ Activation of Grape Seeds. Chem. Eng. Commun. 203, 103-113. https://doi.org/10.1080/00986445.2014.934447

Alonso, D.M., Wettstein, S.G., Dumesic, J.A., 2012. Bimetallic catalysts for upgrading of biomass to fuels and chemicals. Chem. Soc. Rev. 41, 8075. https://doi.org/10.1039/c2cs35188a 
Arvanitoyannis, I.S., Ladas, D., Mavromatis, A., 2008. Wine Waste Management : Treatment Methods Treated Waste, Waste Management for the Food Industries. Elsevier Inc. https://doi.org/10.1016/B978-0-12-373654-3.50010-9

Aurand, J.M., 2015. State of the Vitiviniculture World Market. 38th OIV World Congr. vine wine $1-14$.

Bhoyate, S., Ranaweera, C.K., Zhang, C., Morey, T., Hyatt, M., Kahol, P.K., Ghimire, M., Mishra, S.R., Gupta, R.K., 2017. Eco-Friendly and High Performance Supercapacitors for Elevated Temperature Applications Using Recycled Tea Leaves. Glob. Challenges 1700063, 1700063. https://doi.org/10.1002/gch2.201700063

Brandt, A., Gräsvik, J., Hallett, J.P., Welton, T., 2013. Deconstruction of lignocellulosic biomass with ionic liquids. Green Chem. 15, 550. https://doi.org/10.1039/c2gc36364j

Bustamante, M.A., Moral, R., Paredes, C., Pérez-Espinosa, A., Moreno-Caselles, J., PérezMurcia, M.D., 2008. Agrochemical characterisation of the solid by-products and residues from the winery and distillery industry. Waste Manag. 28, 372-380. https://doi.org/10.1016/j.wasman.2007.01.013

Centeno, T.A., Stoeckli, F., 2010. The assessment of surface areas in porous carbons by two model-independent techniques, the DR equation and DFT. Carbon N. Y. 48, 2478-2486. https://doi.org/10.1016/j.carbon.2010.03.020

Deiana, A.C., Gimenez, M., Sardella, M.F., Sapag, K., Masseo, A.L.S., Teixeira, A.P.C., Araujoc, M.H., Lago, R.M., 2014. Catalytic oxidation of aqueous sulfide promoted by oxygen functionalities on the surface of activated carbon briquettes produced from viticulture wastes. J. Braz. Chem. Soc. 25, 2392-2398. https://doi.org/10.5935/01035053.20140265

Deiana, A.C., Gimenez, M.G., Rómoli, S., Sardella, M.F., Sapag, K., 2014. Batch and Column Studies for the Removal of Lead from Aqueous Solutions Using Activated Carbons from Viticultural Industry Wastes. Adsorpt. Sci. Technol. 32, 181-196. https://doi.org/10.1260/0263-6174.32.2-3.181

Deiana, A.C., Sardella, M.F., Silva, H., Amaya, A., Tancredi, N., 2009. Use of grape stalk, a waste of the viticulture industry, to obtain activated carbon. J. Hazard. Mater. 172, 1319. https://doi.org/10.1016/j.jhazmat.2009.06.095

Demiral, H., 2016. Adsorption of copper ( II ) from aqueous solutions on activated carbon prepared from grape bagasse. J. Clean. Prod. 124, 103-113. 
https://doi.org/10.1016/j.jclepro.2016.02.084

Devesa-Rey, R., Vecino, X., Varela-Alende, J.L., Barral, M.T., Cruz, J.M., Moldes, A.B., 2011. Valorization of winery waste vs. the costs of not recycling. Waste Manag. 31, 2327-2335. https://doi.org/10.1016/j.wasman.2011.06.001

Donar, Y.O., Çağlar, E., Sinağ, A., 2016. Preparation and characterization of agricultural waste biomass based hydrochars. Fuel 183, 366-372. https://doi.org/10.1016/j.fuel.2016.06.108

Dwyer, K., Hosseinian, F., Rod, M., 2014. The Market Potential of Grape Waste Alternatives. J. Food Res. 3, 91. https://doi.org/10.5539/jfr.v3n2p91

El Achkar, J.H., Lendormi, T., Hobaika, Z., Salameh, D., Louka, N., Maroun, R.G., Lanoisellé, J.L., 2016. Anaerobic digestion of grape pomace: Biochemical characterization of the fractions and methane production in batch and continuous digesters. Waste Manag. 50, 275-282. https://doi.org/10.1016/j.wasman.2016.02.028

Figueiredo, J.L., Pereira, M.F.R., Freitas, M.M.A., Órfão, J.J.M., 2007. Characterization of active sites on carbon catalysts. Ind. Eng. Chem. Res. 46, 4110-4115. https://doi.org/10.1021/ie061071v

Gergova, K., Petrov, N., Eser, S., 1994. Adsorption properties and microstructure of activated carbons produced from agricultural by-products by steam pyrolysis. Carbon N. Y. 32, 693-702. https://doi.org/10.1016/0008-6223(94)90091-4

Gollakota, A.R.K., Kishore, N., Gu, S., 2016. A review on hydrothermal liquefaction of biomass. Renew. Sustain. Energy Rev. 81, 1378-1392. https://doi.org/10.1016/j.rser.2017.05.178

González-Paramás, A.M., Esteban-Ruano, S., Santos-Buelga, C., De Pascual-Teresa, S., Rivas-Gonzalo, J.C., 2004. Flavanol Content and Antioxidant Activity in Winery Byproducts. J. Agric. Food Chem. 52, 234-238. https://doi.org/10.1021/jf0348727

Güzel, F., Sayğili, H., 2016. Adsorptive efficacy analysis of novel carbonaceous sorbent derived from grape industrial processing wastes towards tetracycline in aqueous solution. J. Taiwan Inst. Chem. Eng. 60, 236-240. https://doi.org/10.1016/j.jtice.2015.10.003 Islam, M.A., Tan, I.A.W., Benhouria, A., Asif, M., Hameed, B.H., 2015. Mesoporous and adsorptive properties of palm date seed activated carbon prepared via sequential hydrothermal carbonization and sodium hydroxide activation. Chem. Eng. J. 270, 187195. https://doi.org/10.1016/j.cej.2015.01.058 
ISO [International Organization for Standardization], 2010. Determination of the specific surface area of solids by gas adsorption - BET method (ISO 9277:2010(E)). Ref. number ISO 9277, 30 pp. https://doi.org/10.1007/s11367-011-0297-3

Jain, A., Balasubramanian, R., Srinivasan, M.P., 2016. Hydrothermal conversion of biomass waste to activated carbon with high porosity: A review. Chem. Eng. J. 283, 789-805. https://doi.org/10.1016/j.cej.2015.08.014

Jimenez-Cordero, D., Heras, F., Alonso-Morales, N., Gilarranz, M.A., Rodriguez, J.J., 2015. Ozone as oxidation agent in cyclic activation of biochar. Fuel Process. Technol. 139, 4248. https://doi.org/10.1016/j.fuproc.2015.08.016

Jimenez-Cordero, D., Heras, F., Alonso-Morales, N., Gilarranz, M.A., Rodríguez, J.J., 2014. Preparation of granular activated carbons from grape seeds by cycles of liquid phase oxidation and thermal desorption. Fuel Process. Technol. 118, 148-155. https://doi.org/10.1016/j.fuproc.2013.08.019

Jimenez-Cordero, D., Heras, F., Alonso-Morales, N., Gilarranz, M.A., Rodriguez, J.J., 2013. Development of porosity upon physical activation of grape seeds char by gas phase oxygen chemisorption-desorption cycles. Chem. Eng. J. 231, 172-181. https://doi.org/10.1016/j.cej.2013.07.005

Kambo, H.S., Dutta, A., 2015. A comparative review of biochar and hydrochar in terms of production, physico-chemical properties and applications. Renew. Sustain. Energy Rev. https://doi.org/10.1016/j.rser.2015.01.050

Kang, S., Li, X., Fan, J., Chang, J., 2012. Characterization of hydrochars produced by hydrothermal carbonization of lignin, cellulose, d-xylose, and wood meal. Ind. Eng. Chem. Res. 51, 9023-9031. https://doi.org/10.1021/ie300565d

Lee, S.Y., Park, S.J., 2015. A review on solid adsorbents for carbon dioxide capture. J. Ind. Eng. Chem. 23, 1-11. https://doi.org/10.1016/j.jiec.2014.09.001

Lobato, B., Suárez, L., Guardia, L., Centeno, T.A., 2017. Capacitance and surface of carbons in supercapacitors. Carbon N. Y. 122, 434-445. https://doi.org/10.1016/j.carbon.2017.06.083

Lozano-Castelló, D., Cazorla-Amorós, D., Linares-Solano, A., 2004. Usefulness of CO2 adsorption at $273 \mathrm{~K}$ for the characterization of porous carbons. Carbon N. Y. 42, 12311236. https://doi.org/10.1016/j.carbon.2004.01.037

Lucian, M., Fiori, L., 2017. Hydrothermal carbonization of waste biomass: Process design, 
modeling, energy efficiency and cost analysis. Energies 10, 1-5. https://doi.org/10.3390/en10020211

Mäkelä, M., Kwong, C.W., Broström, M., Yoshikawa, K., 2017. Hydrothermal treatment of grape marc for solid fuel applications. Energy Convers. Manag. 145, 371-377. https://doi.org/10.1016/j.enconman.2017.05.015

Marco-Lozar, J.P., Kunowsky, M., Suárez-García, F., Linares-Solano, A., 2014. Sorbent design for CO2 capture under different flue gas conditions. Carbon N. Y. 72, 125-134. https://doi.org/10.1016/j.carbon.2014.01.064

Martín, C.F., Plaza, M.G., Pis, J.J., Rubiera, F., Pevida, C., Centeno, T.A., 2010. On the limits of CO2 capture capacity of carbons. Sep. Purif. Technol. 74, 225-229. https://doi.org/10.1016/j.seppur.2010.06.009

Martínez, N.D., Venturini, R.B., Silva, H.S., González, J.E., Rodríguez, A.M., 2009. Copper on activated carbon for catalytic wet air oxidation. Mater. Res. 12, 45-50.

Mechati, F., Bouchelta, C., Medjram, M.S., Benrabaa, R., Ammouchi, N., 2015. Effect of hard and soft structure of different biomasses on the porosity development of activated carbon prepared under $\mathrm{N}<\mathrm{inf}>2</ \mathrm{inf}>/$ microwave radiations. J. Environ. Chem. Eng. 3, 1928-1938. https://doi.org/10.1016/j.jece.2015.07.007

Mena, I.F., Diaz, E., Rodriguez, J.J., Mohedano, A.F., 2017. CWPO of bisphenol A with iron catalysts supported on microporous carbons from grape seeds activation. Chem. Eng. J. 318, 153-160. https://doi.org/10.1016/j.cej.2016.06.029

Muhlack, R.A., Potumarthi, R., Jeffery, D.W., 2017. Sustainable wineries through waste valorisation: A review of grape marc utilisation for value-added products. Waste Manag. https://doi.org/10.1016/j.wasman.2017.11.011

O’Grady, M.N., Carpenter, R., Lynch, P.B., O’Brien, N.M., Kerry, J.P., 2008. Addition of grape seed extract and bearberry to porcine diets: Influence on quality attributes of raw and cooked pork. Meat Sci. 78, 438-446. https://doi.org/10.1016/j.meatsci.2007.07.011

Okman, I., Karagöz, S., Tay, T., Erdem, M., 2014. Activated carbons from grape seeds by chemical activation with potassium carbonate and potassium hydroxide. Appl. Surf. Sci. 293, 138-142. https://doi.org/10.1016/j.apsusc.2013.12.117

Özçimen, D., Ersoy-Meriçboyu, A., 2009. Removal of copper from aqueous solutions by adsorption onto chestnut shell and grapeseed activated carbons. J. Hazard. Mater. 168, 1118-1125. https://doi.org/10.1016/j.jhazmat.2009.02.148 
Ozdemir, I., Şahin, M., Orhan, R., Erdem, M., 2014. Preparation and characterization of activated carbon from grape stalk by zinc chloride activation. Fuel Process. Technol. 125, 200-206. https://doi.org/10.1016/j.fuproc.2014.04.002

Pala, M., Kantarli, I.C., Buyukisik, H.B., Yanik, J., 2014. Hydrothermal carbonization and torrefaction of grape pomace: A comparative evaluation. Bioresour. Technol. 161, 255262. https://doi.org/10.1016/j.biortech.2014.03.052

Pettersen, R.C., 1984. The Chemical Composition of Wood, in: The Chemistry of Solid Wood, Advances in Chemistry. American Chemical Society, pp. 2-57. https://doi.org/doi:10.1021/ba-1984-0207.ch002

Rouquerol, J., Llewellyn, P., Rouquerol, F., 2007. Is the bet equation applicable to microporous adsorbents? 2991, 49-56. https://doi.org/10.1016/S0167-2991(07)80008-5

Ruiz, B., Ruisánchez, E., Gil, R.R., Ferrera-Lorenzo, N., Lozano, M.S., Fuente, E., 2015. Sustainable porous carbons from lignocellulosic wastes obtained from the extraction of tannins. Microporous Mesoporous Mater. 209, 23-29. https://doi.org/10.1016/j.micromeso.2014.09.004

Sabio, E., Álvarez-Murillo, A., Román, S., Ledesma, B., 2016. Conversion of tomato-peel waste into solid fuel by hydrothermal carbonization: Influence of the processing variables. Waste Manag. 47, 122-132. https://doi.org/10.1016/j.wasman.2015.04.016

Sardella, F., Gimenez, M., Navas, C., Morandi, C., Deiana, C., Sapag, K., 2015. Conversion of viticultural industry wastes into activated carbons for removal of lead and cadmium. J. Environ. Chem. Eng. 3, 253-260. https://doi.org/10.1016/j.jece.2014.06.026

Savova, D., Apak, E., Ekinci, E., Yardim, F., Petrov, N., Budinova, T., Razvigorova, M., Minkova, V., 2001. Biomass conversion to carbon adsorbents and gas. Biomass and Bioenergy 21, 133-142. https://doi.org/10.1016/S0961-9534(01)00027-7

Sayğili, H., Güzel, F., 2015. Performance of new mesoporous carbon sorbent prepared from grape industrial processing wastes for malachite green and congo red removal. Chem. Eng. Res. Des. 100, 27-38. https://doi.org/10.1016/j.cherd.2015.05.014

Sayğili, H., Güzel, F., Önal, Y., 2015. Conversion of grape industrial processing waste to activated carbon sorbent and its performance in cationic and anionic dyes adsorption. $\mathrm{J}$. Clean. Prod. 93, 84-93. https://doi.org/10.1016/j.jclepro.2015.01.009

Schuerch, C., 1968. Methods of wood chemistry. vol. II. B. L. Browning, Ed., Wiley, New York, 1967. 498 pp. \$18.75. J. Polym. Sci. Part A-2 Polym. Phys. 6, 1943-1944. 
https://doi.org/10.1002/pol.1968.160061112

Suhas, Carrott, P.J.M., Ribeiro Carrott, M.M.L., 2007. Lignin - from natural adsorbent to activated carbon: A review. Bioresour. Technol. 98, 2301-2312. https://doi.org/10.1016/j.biortech.2006.08.008

Szymánski, G.S., Karpi'nski, Z., Biniak, S., Swiatkowski, A., 2002. The effect of the gradual thermal decomposition of surface oxygen species on the chemical and catalytic properties of oxidized activated carbon. Carbon N. Y. 40, 2627-2639. https://doi.org/10.1016/S0008-6223(02)00188-4

Thommes, M., Kaneko, K., Neimark, A. V., Olivier, J.P., Rodriguez-Reinoso, F., Rouquerol, J., Sing, K.S.W., 2015. Physisorption of gases, with special reference to the evaluation of surface area and pore size distribution (IUPAC Technical Report). Pure Appl. Chem. 87, 1051-1069. https://doi.org/10.1515/pac-2014-1117

Tian, Y., Wu, J., 2018. A comprehensive analysis of the BET area for nanoporous materials. AIChE J. 64, 286-293. https://doi.org/10.1002/aic.15880

Titirici, M.-M., White, R.J., Brun, N., Budarin, V.L., Su, D.S., del Monte, F., Clark, J.H., MacLachlan, M.J., 2015. Sustainable carbon materials. Chem. Soc. Rev. 44, 250-290. https://doi.org/10.1039/C4CS00232F

Toscano, G., Riva, G., Duca, D., Pedretti, E.F., Corinaldesi, F., Rossini, G., 2013. Analysis of the characteristics of the residues of the wine production chain finalized to their industrial and energy recovery. Biomass and Bioenergy 55, 260-267. https://doi.org/10.1016/j.biombioe.2013.02.015

Tsoncheva, T., Velinov, N., Ivanova, R., Stoycheva, I., Tsyntsarski, B., Spassova, I., Paneva, D., Issa, G., Kovacheva, D., Genova, I., Mitov, I., Petrov, N., 2015. Formation of catalytic active sites in iron modified activated carbons from agriculture residues. Microporous Mesoporous Mater. 217, 87-95. https://doi.org/10.1016/j.micromeso.2015.06.008

Van Krevelen, D., 1950. Graphical statistical method for the study of structure and reaction processes of coal.

Wiedner, K., Rumpel, C., Steiner, C., Pozzi, A., Maas, R., Glaser, B., 2013. Chemical evaluation of chars produced by thermochemical conversion (gasification, pyrolysis and hydrothermal carbonization) of agro-industrial biomass on a commercial scale. Biomass and Bioenergy 59, 264-278. https://doi.org/10.1016/j.biombioe.2013.08.026 
Yedro, F.M., García-Serna, J., Cantero, D.A., Sobrón, F., Cocero, M.J., 2015. Hydrothermal fractionation of grape seeds in subcritical water to produce oil extract, sugars and lignin. Catal. Today 257, 160-168. https://doi.org/10.1016/j.cattod.2014.07.053

Zhang, J., Zhao, X.S., 2012. On the configuration of supercapacitors for maximizing electrochemical performance. ChemSusChem 5, 818-841. https://doi.org/10.1002/cssc.201100571

Zhang, N., Hoadley, A., Patel, J., Lim, S., Li, C., 2017. Sustainable options for the utilization of solid residues from wine production. Waste Manag. 60, 173-183. https://doi.org/10.1016/j.wasman.2017.01.006

Zhu, Y., Murali, S., Stoller, M.D., Ganesh, K.J., Cai, W., Ferreira, P.J., Pirkle, A., Wallace, R.M., Cychosz, K.A., Thommes, M., Su, D., Stach, E.A., Ruoff, R.S., 2011. CarbonBased Supercapacitors Produced by Activation of Graphene. Science (80-. ). 332, 1537 LP-1541.

Zielke, U., Huttinger, K.J., Hoffman, W.P., 1996. Surface-oxidized carbon fibers .1. Surface structure and chemistry. Carbon N. Y. 34, 983-998. https://doi.org/10.1016/00086223(96)00032-2 


\section{Table Captions}

Table 1. Summary of activated carbons obtained from winery wastes.

Table 2. Composition of winery wastes (wt\% dry basis).

Table 3. Elemental analysis and surface oxygenated groups determined by TPD of feedstocks, hydrochars and activated carbons.

Table 4. Porosity features of the activated carbons derived from winery wastes.

Table 5. $\mathrm{CO}_{2}$ capture capacity and electrochemical capacitance of activated carbons derived from winery wastes.

\section{Figure Captions}

Figure 1. $\mathrm{CO}_{2}$ and $\mathrm{CO}$ release in TPD experiments.

Figure 2. Van Krevelen diagram of raw biomass, hydrochars and activated carbons.

Inset: Relative position of the different set of samples as consequence of primary processes: demethanation (red line), dehydration (purple line) and decarboxylation (green line).

Figure 3. SEM images of the winery wastes and the corresponding hydrocarbons and activated carbons.

Figure 4. Pore size distribution in the activated carbons derived from winery residues. NLDFT analysis of $\mathrm{CO}_{2}$ adsorption (----) and QSDFT analysis of $\mathrm{N}_{2}$ adsorption (- - -) are combined.

Figure 5. Correlation between the yield and the specific surface area for the different processes on winery wastes. 
Figure 6. Galvanostatic charge-discharge curves of the supercapacitors based on carbons obtained from $\mathrm{KOH}$ activation of grape seeds. 
Figure 1.
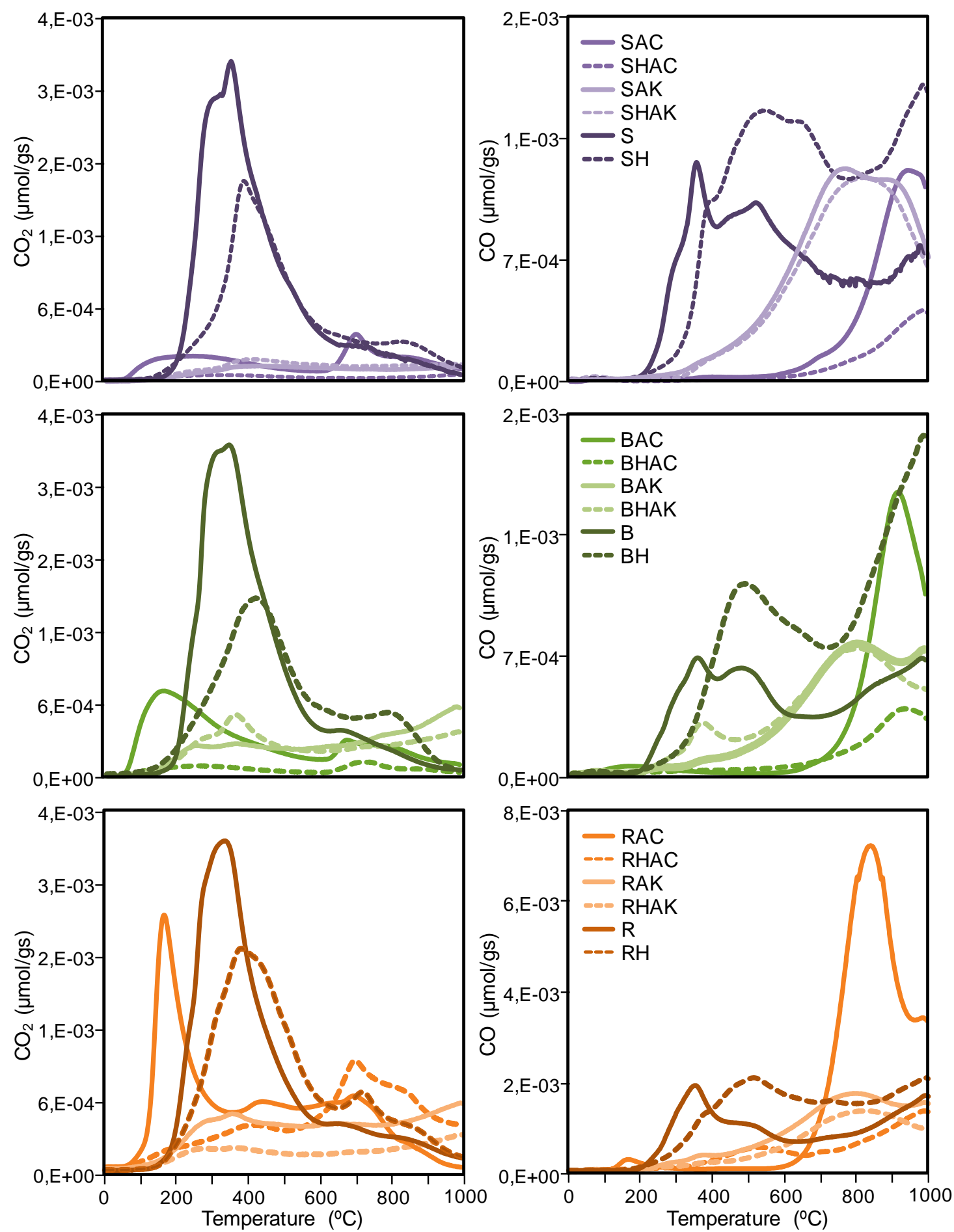
Figure 2.

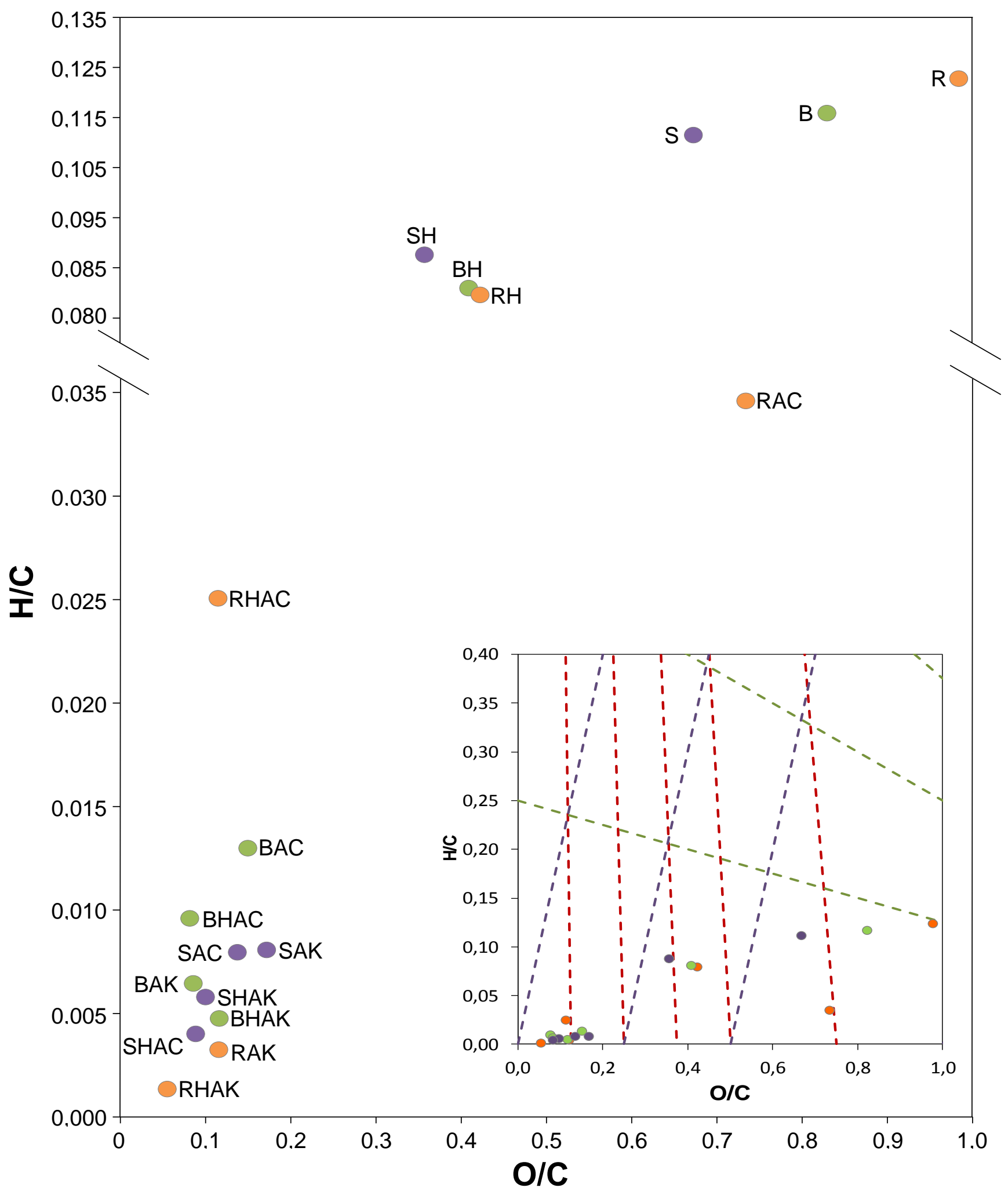


Figure 3.

\section{OIL-FREE SEEDS}
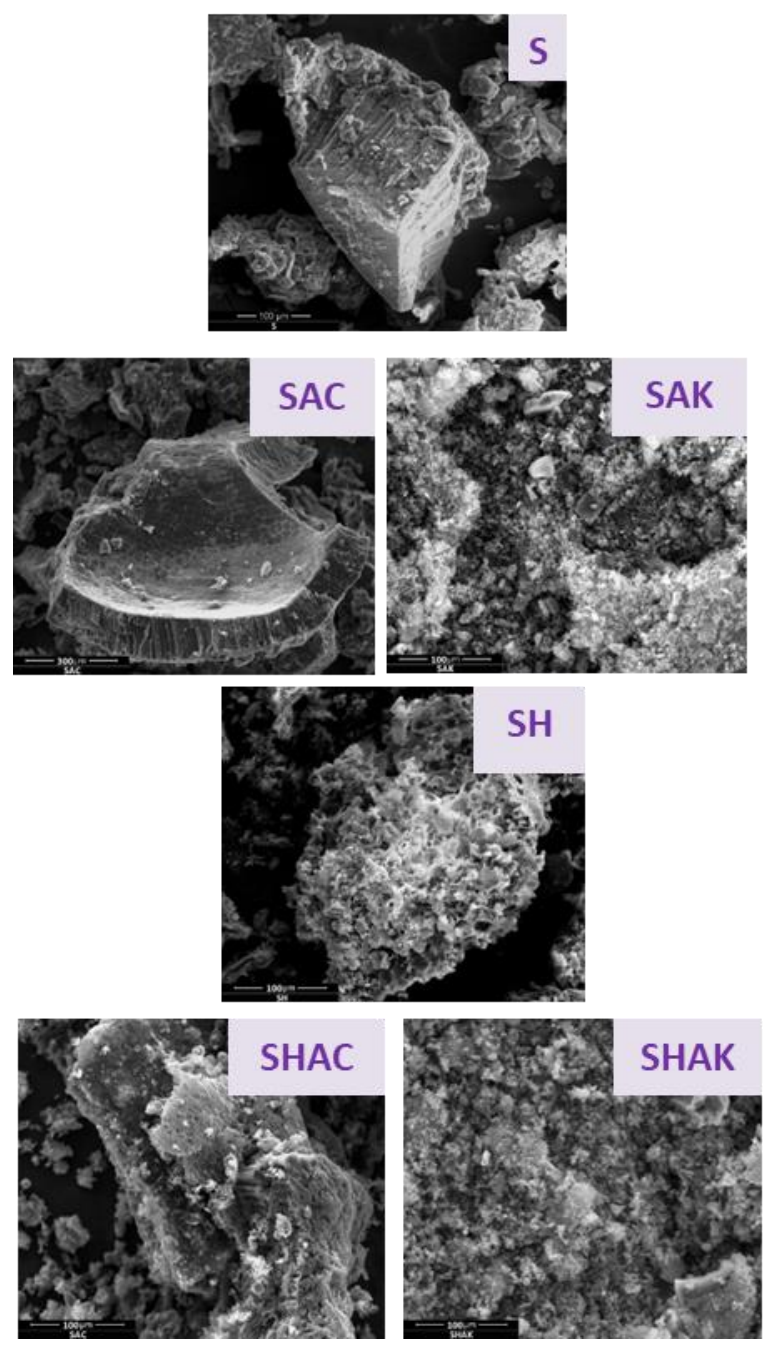

BAGASSE
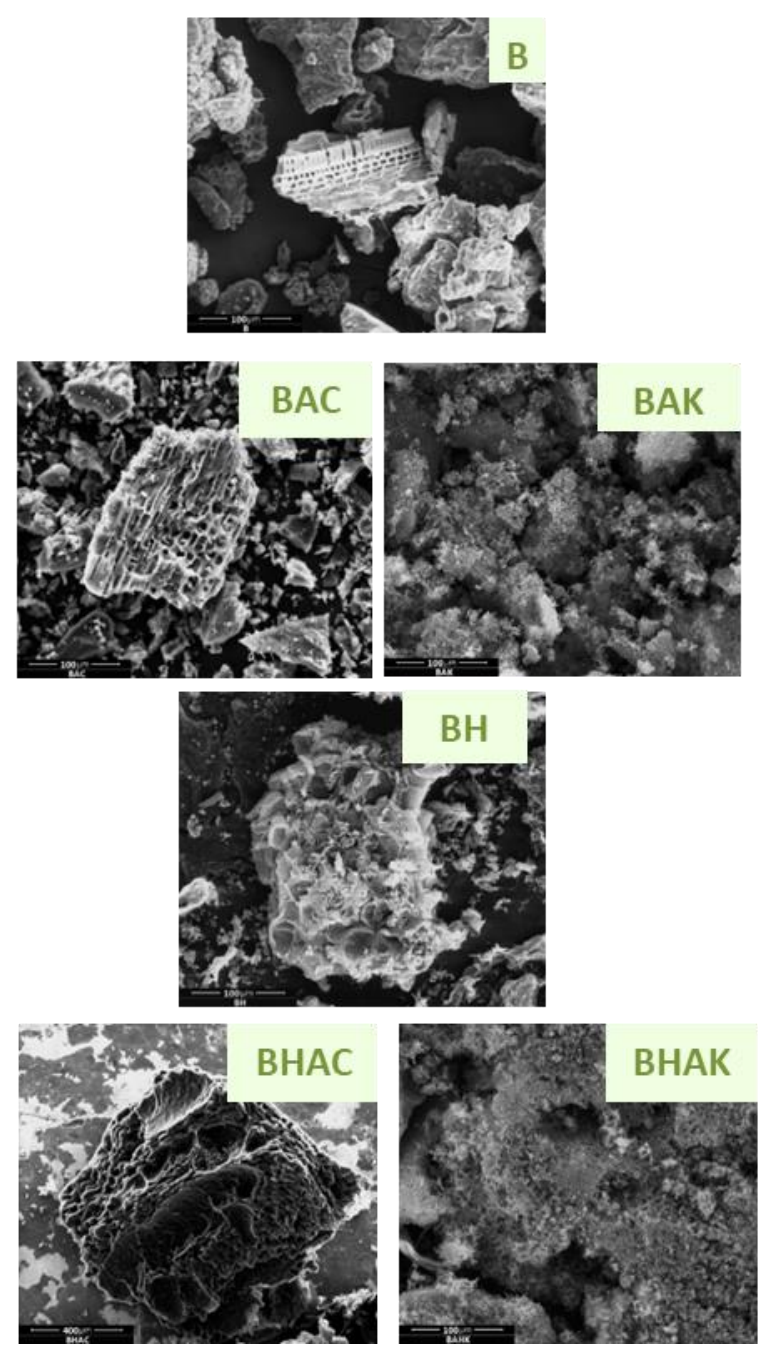

STALKS
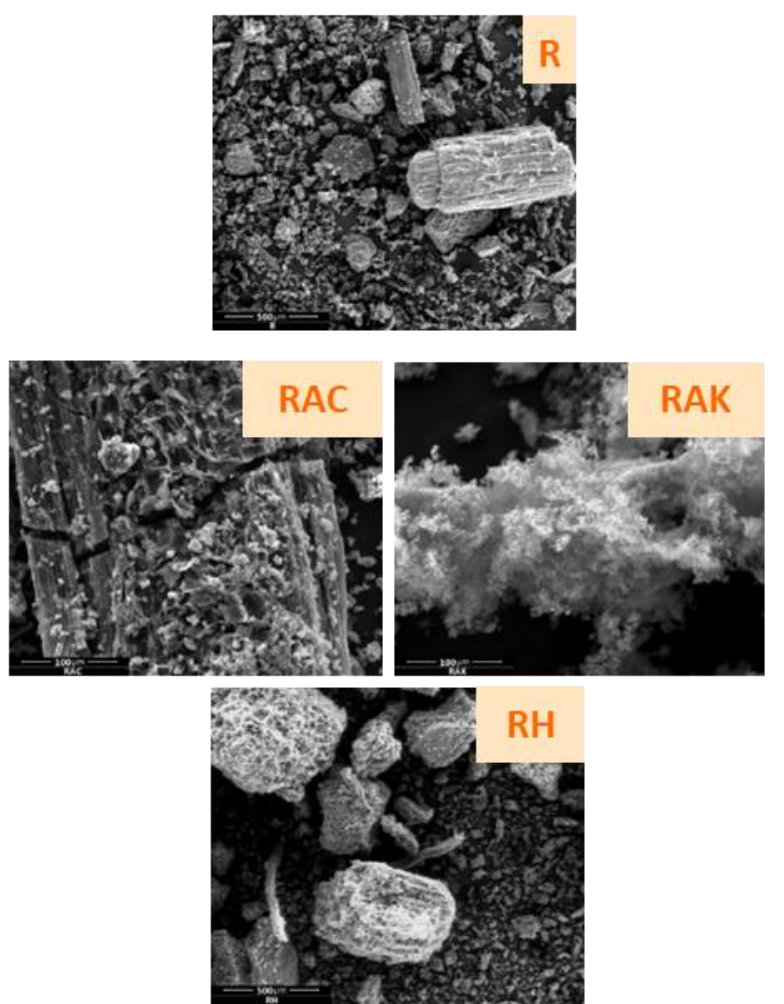

RHAC

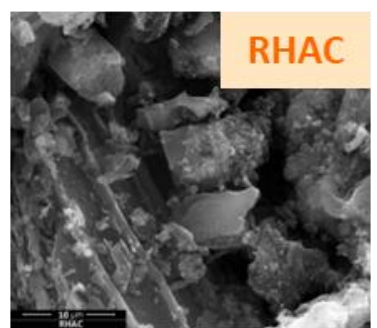

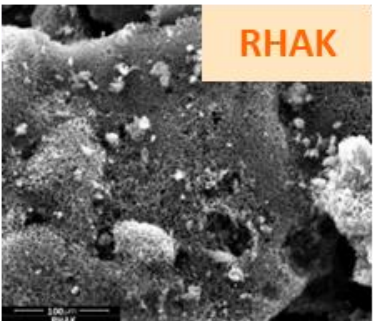


Figure 4.

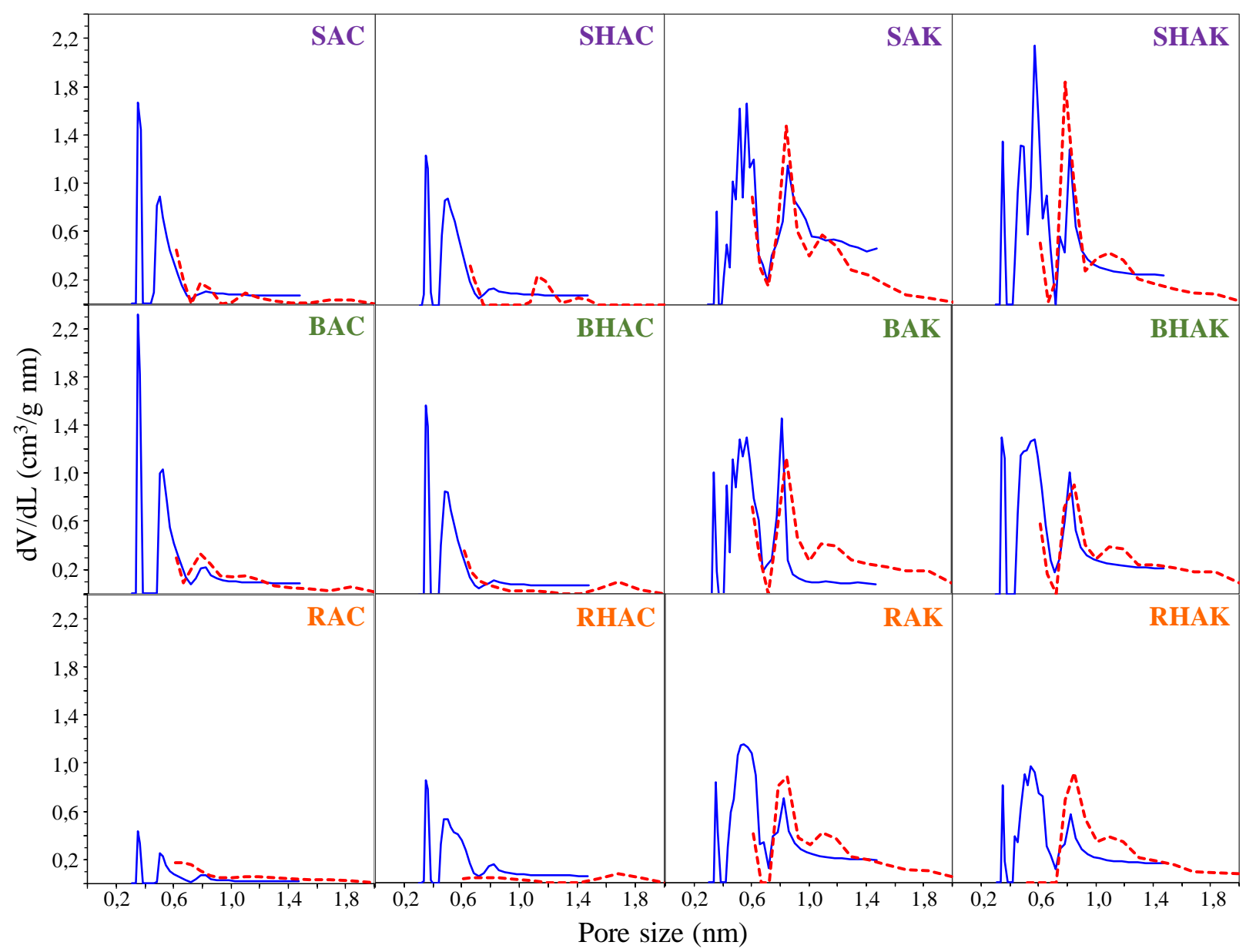


Figure 5.

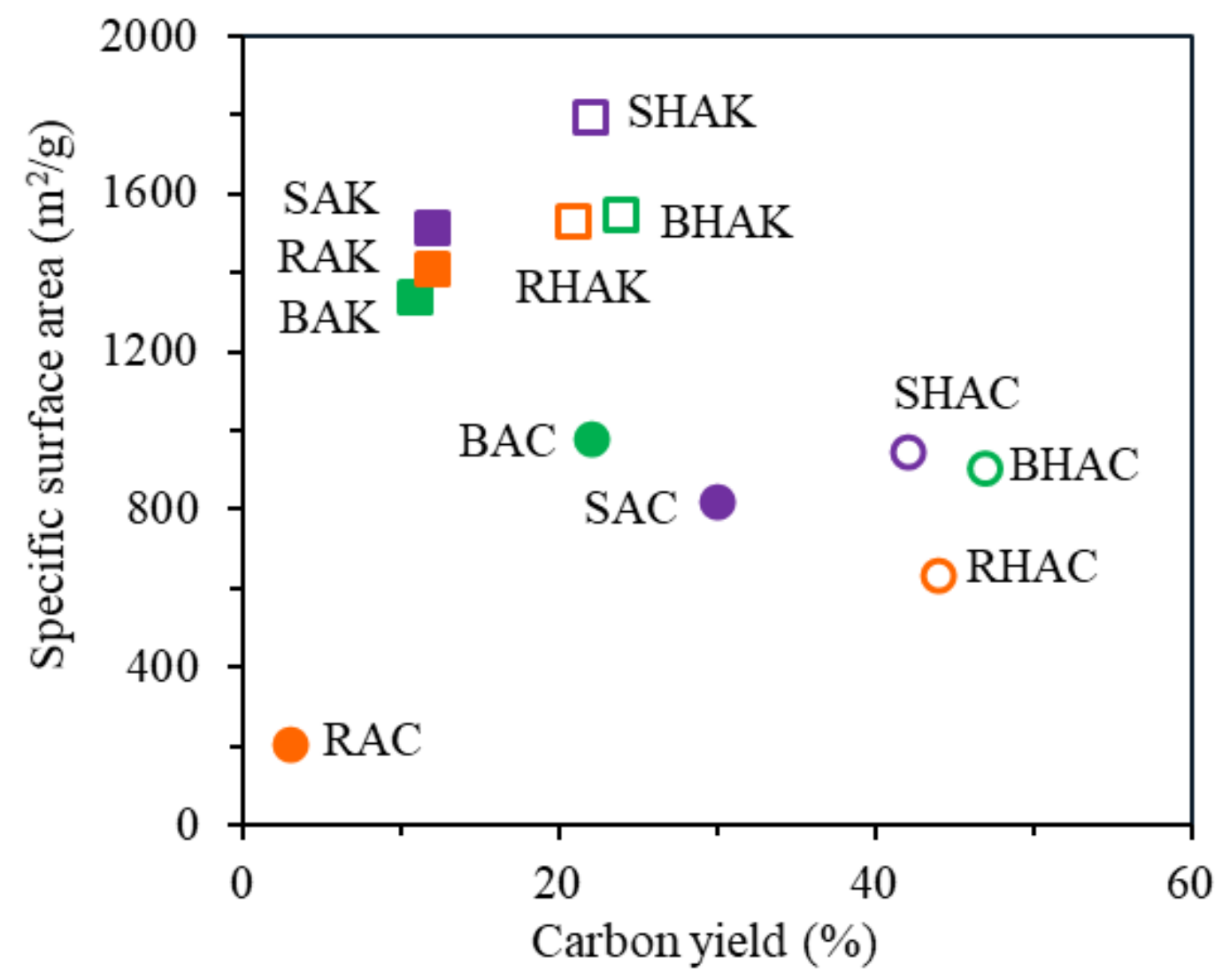



Figure 6.

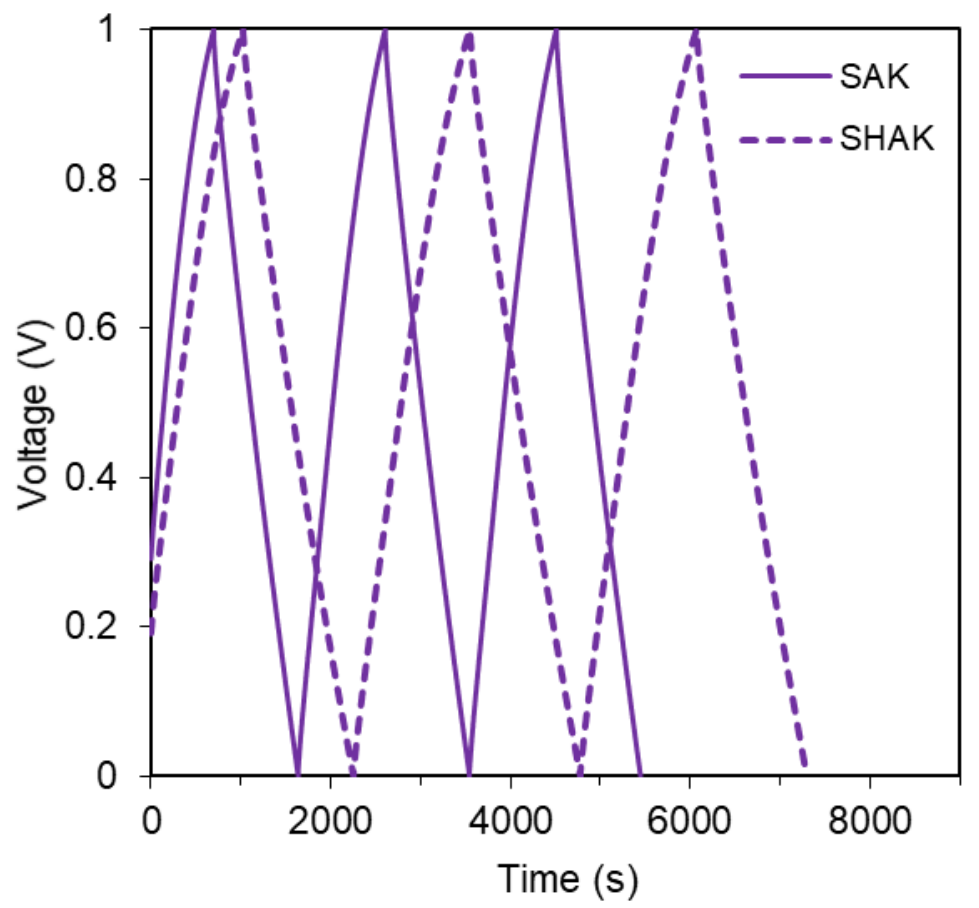




\section{Table 1.}

\begin{tabular}{|c|c|c|c|c|}
\hline Precursor & Activation process & $\begin{array}{l}\mathrm{S}_{\mathrm{BET}} \\
\left(\mathrm{m}^{2} / \mathrm{g}\right)\end{array}$ & Application & Reference \\
\hline Grape seeds & 1step-Steam & 497 & - & (Savova et al., 2001) \\
\hline Grape seeds & 1 step-Steam & 403 & - & (Gergova et al., 1994) \\
\hline Grape stalk & $\begin{array}{l}2 \text { steps-Steam } \\
\text { Prior HCl leaching }\end{array}$ & $105-923$ & ( & (Deiana et al., 2014a) \\
\hline Grape stalk and pomace & $\begin{array}{l}2 \text { steps-Steam } \\
\text { Prior HCl leaching }\end{array}$ & $285-923$ & $\begin{array}{l}\text { Catalytic oxidation of aqueous sulphide } \\
\mathrm{Pb} \text { removal from aqueous solutions }\end{array}$ & (Deiana et al., 2014b) \\
\hline Grape stalks & 2 steps-Steam & 846 & Catalytic Wet Air Oxidation & (Martínez et al., 2009) \\
\hline Grape stalk, lex and pomace & 2 steps-Steam & $266-798$ & $\mathrm{~Pb}, \mathrm{Cd}$ removal & (Sardella et al., 2015) \\
\hline Grape seeds & 2 steps-Air & 440 & $\begin{array}{l}\text { Catalytic wet peroxide oxidation of } \\
\text { bisphenol A }\end{array}$ & (Mena et al., 2017) \\
\hline Grape seeds & 2 steps-Steam & 603 & Formation of iron catalytic sites & (Tsoncheva et al., 2015) \\
\hline Grape seeds & 2 steps- $\mathrm{CO}_{2}$ & $380-714$ & Diuron adsorption from water & (Al Bahri et al., 2016) \\
\hline Grape stalk & 1 step- $\mathrm{H}_{3} \mathrm{PO}_{4}$ & $1000-1676$ & - & (Deiana et al., 2009) \\
\hline Grape bagasse & 1 step- $\mathrm{H}_{3} \mathrm{PO}_{4}$ & $292-1455$ & $\mathrm{Cu}$ removal from aqueous solutions & (Demiral, 2016) \\
\hline Grape seeds & 2 steps $\mathrm{H}_{2} \mathrm{SO}_{4} / \mathrm{H}_{3} \mathrm{PO}_{4}$ & $657-1139$ & Diuron adsorption from water & (Al Bahri et al., 2012) \\
\hline $\begin{array}{l}\text { Residue of extraction of } \\
\text { tannins from grape seeds }\end{array}$ & 2 step-KOH & $1038-1860$ & Adsorption of $\mathrm{CO}_{2}, \mathrm{CH}_{4}$ and $\mathrm{H}_{2}$ & (Ruiz et al., 2015) \\
\hline Grape seeds & 1 step- $\mathrm{K}_{2} \mathrm{CO}_{3} / \mathrm{KOH}$ & $33-1238$ & - & (Okman et al., 2014) \\
\hline Grape seeds & 1 step- $\mathrm{ZnCl}_{2}$ & 916 & $\mathrm{Cu}$ removal from aqueous solutions & (Özçimen and Ersoy-Meriçboyu, 2009) \\
\hline Grape processing wastes & 1 step- $\mathrm{ZnCl}_{2}$ & $819-1455$ & Cationic and anionic dyes adsorption & (Sayğili et al., 2015) \\
\hline
\end{tabular}




\begin{tabular}{|c|c|c|c|c|}
\hline Grape pulp & 1 step- $\mathrm{ZnCl}_{2}$ & 1455 & $\begin{array}{l}\text { Tetracyclinein adsorption } \\
\text { Dyes adsorption }\end{array}$ & $\begin{array}{l}\text { (Güzel and Sayğili, 2016; Sayğili and } \\
\text { Güzel, 2015) }\end{array}$ \\
\hline Grape stalk & 1 step- $\mathrm{ZnCl}_{2} / \mathrm{CO}_{2}$ & $211-1412$ & - & (Ozdemir et al., 2014) \\
\hline Grape stalk & 2 steps- $\mathrm{H}_{2} \mathrm{SO}_{4} /$ Microwave & 530 & - & (Mechati et al., 2015) \\
\hline $\begin{array}{l}\text { Grape seeds pre-treated by } \\
\text { hexane extraction to remove } \\
\text { oil }\end{array}$ & $\begin{array}{l}\text { Gas phase oxygen } \\
\text { chemisorption-desorption } \\
\text { cycles on seeds-char }\end{array}$ & $\begin{array}{l}1129-1256 \\
\mathrm{~S}_{\mathrm{CO} 2} \sim 1250\end{array}$ & - & (Jimenez-Cordero et al., 2013) \\
\hline $\begin{array}{l}\text { Grape seeds pre-treated by } \\
\text { hexane extraction to remove } \\
\text { oil }\end{array}$ & $\begin{array}{l}\text { Cycles of liquid phase } \\
\text { oxidation and thermal } \\
\text { desorption on seeds-char }\end{array}$ & $600-1450$ & - & (Jimenez-Cordero et al., 2014) \\
\hline $\begin{array}{l}\text { Grape seeds pre-treated by } \\
\text { hexane to remove oil }\end{array}$ & $\begin{array}{l}\text { Cyclic treatments with } \\
\text { ozone on seeds-char }\end{array}$ & $\begin{array}{c}350-1200 \\
\mathrm{~S}_{\mathrm{CO} 2} \sim 1500\end{array}$ & & (Jimenez-Cordero et al., 2015) \\
\hline
\end{tabular}


Table 2.

\begin{tabular}{lccccc}
\hline \multicolumn{1}{c}{ Winery waste } & Cellulose & Hemicellulose & Lignin & Extractives & Ash \\
\hline Oil-free Seeds (S) & $14 \pm 1$ & $24 \pm 4$ & $36 \pm 2$ & $23 \pm 4$ & $3 \pm 1$ \\
Bagasse (B) & $17 \pm 1$ & $22 \pm 2$ & $33 \pm 3$ & $22 \pm 1$ & $6 \pm 1$ \\
Stalks (R) & $10 \pm 1$ & $12 \pm 2$ & $40 \pm 4$ & $33 \pm 3$ & $6 \pm 1$ \\
\hline
\end{tabular}




\begin{tabular}{|c|c|c|c|c|c|c|c|c|c|c|}
\hline \multirow{2}{*}{$\begin{array}{l}\text { Winery } \\
\text { waste }\end{array}$} & \multirow{2}{*}{ Sample } & \multirow{2}{*}{$\begin{array}{c}\text { Ash } \\
(\text { wt \%) }\end{array}$} & \multicolumn{4}{|c|}{ Elemental analysis (wt \%, } & \multicolumn{4}{|c|}{ Surface oxygenated groups } \\
\hline & & & $\mathrm{C}$ & $\mathrm{H}$ & $\mathrm{N}$ & $\mathrm{O}$ & $\begin{array}{c}{\left[\mathrm{CO}_{2}\right]} \\
(\mu \mathrm{mol} / \mathrm{g})\end{array}$ & $\begin{array}{c}{[\mathrm{CO}]} \\
(\mu \mathrm{mol} / \mathrm{g})\end{array}$ & $\begin{array}{c}{[\mathrm{O}]=2\left[\mathrm{CO}_{2}\right]+[\mathrm{CO}]} \\
(\mu \mathrm{mol} / \mathrm{g})\end{array}$ & $\begin{array}{l}{[\mathrm{O}] / \mathrm{S}_{\text {total }}} \\
\left(\mu \mathrm{mol} / \mathrm{m}^{2}\right)\end{array}$ \\
\hline \multirow{6}{*}{$\begin{array}{l}\text { Oil free- } \\
\text { seeds }\end{array}$} & Feedstock-S & 3.5 & 55.4 & 6.2 & 1.4 & 37.0 & 2526 & 2919 & 7971 & - \\
\hline & SH & 2.6 & 68.1 & 5.9 & 1.7 & 24.2 & 1456 & 3266 & 6177 & 96.5 \\
\hline & SAC & 9.2 & 86.0 & 0.7 & 1.6 & 11.7 & 688 & 1679 & 3055 & 3.73 \\
\hline & SHAC & 4.6 & 90.2 & 0.4 & 2.1 & 7.4 & 172 & 610 & 954 & 1.00 \\
\hline & SAK & 3.3 & 84.8 & 0.7 & 0.3 & 14.2 & 451 & 2484 & 3386 & 2.24 \\
\hline & SHAK & 2.1 & 90.5 & 0.5 & 0.2 & 8.7 & 569 & 2501 & 3640 & 2.03 \\
\hline \multirow{6}{*}{ Bagasse } & Feedstock-B & 6.0 & 50.9 & 5.9 & 1.3 & 41.9 & 3442 & 3731 & 10615 & - \\
\hline & $\mathrm{BH}$ & 2.8 & 65.7 & 5.3 & 2.2 & 26.9 & 2719 & 8354 & 13792 & 67.6 \\
\hline & BAC & 17.3 & 83.9 & 1.1 & 2.4 & 12.6 & 1437 & 3234 & 6109 & 6.24 \\
\hline & BHAC & 6.5 & 89.7 & 0.9 & 2.5 & 6.9 & 303 & 1163 & 1769 & 1.95 \\
\hline & BAK & 4.2 & 91.6 & 0.6 & 0.2 & 7.6 & 2063 & 4486 & 8612 & 6.45 \\
\hline & BНАK & 0.1 & 88.8 & 0.4 & 0.4 & 10.3 & 1698 & 3621 & 7017 & 4.54 \\
\hline \multirow{6}{*}{ Stalks } & Feedstock-R & 6.0 & 47.2 & 5.8 & 0.8 & 46.1 & 3939 & 4230 & 12108 & - \\
\hline & RH & 3.2 & 65.9 & 5.2 & 1.3 & 27.8 & 3380 & 5662 & 12422 & 126.8 \\
\hline & RAC & 42.4 & 54.6 & 1.9 & 3.4 & 40.1 & 2730 & 8023 & 13483 & 64.5 \\
\hline & RHAC & 5.2 & 86.3 & 2.2 & 1.8 & 9.8 & 2290 & 2776 & 7357 & 11.6 \\
\hline & RAK & 2.1 & 88.7 & 0.4 & 0.2 & 10.7 & 2669 & 4568 & 9906 & 7.03 \\
\hline & RHAK & 2.7 & 94.5 & 0.1 & 0.2 & 5.2 & 1138 & 3195 & 5471 & 3.58 \\
\hline
\end{tabular}

Table 3. 
Table 4.

\begin{tabular}{|c|c|c|c|c|c|c|c|c|}
\hline \multirow{2}{*}{ Sample } & \multicolumn{5}{|c|}{$\mathrm{N}_{2}$ adsorption } & \multicolumn{3}{|c|}{$\mathrm{CO}_{2}$ adsorption } \\
\hline & $\mathrm{V}_{\text {pores }}$ & $\mathrm{W}_{\mathrm{o}-\mathrm{N} 2}$ & $\mathrm{~L}_{\mathrm{o}-\mathrm{N} 2}$ & $\mathrm{~S}_{\mathrm{N} 2}$ & $\mathrm{~S}_{\mathrm{BET}}$ & $\mathrm{W}_{\mathrm{o}-\mathrm{CO} 2}$ & $\mathrm{~L}_{\mathrm{o}-\mathrm{CO} 2}$ & $\mathrm{~S}_{\mathrm{CO} 2}$ \\
\hline SAC & 0.22 & 0.22 & 0.63 & 703 & 535 & 0.23 & 0.53 & 819 \\
\hline SHAC & 0.14 & 0.14 & 0.73 & 385 & 362 & 0.30 & 0.61 & 950 \\
\hline SAK & 0.83 & 0.82 & 1.16 & 1511 & 2053 & 0.65 & 0.86 & 1512 \\
\hline SHAK & 0.85 & 0.81 & 0.95 & 1791 & 2029 & 0.66 & 0.76 & 1768 \\
\hline BAC & 0.34 & 0.32 & 0.82 & 803 & 809 & 0.31 & 0.60 & 979 \\
\hline BHAC & 0.20 & 0.18 & 0.67 & 562 & 473 & 0.24 & 0.53 & 906 \\
\hline BAK & 0.77 & 0.66 & 1.10 & 1301 & 1717 & 0.52 & 0.78 & 1335 \\
\hline BHAK & 0.75 & 0.66 & 1.01 & 1367 & 1737 & 0.64 & 0.85 & 1545 \\
\hline RAC & - & 0.09 & 1.22 & 164 & 230 & 0.07 & 0.67 & 209 \\
\hline RHAC & - & 0.04 & 1.94 & 38 & 103 & 0.25 & 0.79 & 635 \\
\hline RAK & 0.71 & 0.65 & 0.95 & 1408 & 1682 & 0.47 & 0.75 & 1295 \\
\hline RHAK & 0.73 & 0.67 & 0.92 & 1529 & 1731 & 0.39 & 0.76 & 1051 \\
\hline
\end{tabular}

Table 5.

\begin{tabular}{lccccc}
\hline \multirow{2}{*}{ Carbon } & \multicolumn{2}{c}{$\mathrm{CO}_{2}$ uptake $(w t . \%)$} & & \multicolumn{2}{c}{ Electrochemical capacitance } \\
\cline { 2 - 3 } \cline { 5 - 6 } & 1 bar & $20 \mathrm{bar}$ & & $\mathrm{H}_{2} \mathrm{SO}_{4}$ & $\mathrm{EMImBF}_{4} / \mathrm{AN}$ \\
\hline SAC & $9.9(10.6)^{*}$ & 19.2 & & - & - \\
SHAC & $11.8(11.8)^{*}$ & 23.2 & & - & - \\
SAK & 15.0 & 68.0 & & 289 & 179 \\
SHAK & 15.8 & $68.9(69.4)^{*}$ & & 296 & 145 \\
BAC & 11.5 & 27.7 & & - & - \\
BHAC & 9.8 & 15.9 & & - & - \\
BAK & 13.9 & 55.1 & & 262 & 142 \\
BHAK & 15.4 & 55.7 & & 268 & 142 \\
RAK & 13.2 & $55.3(58.3)^{*}$ & & 269 & 160 \\
RHAK & 10.7 & 57.21 & & 262 & 157 \\
\hline
\end{tabular}

* (Experimental value) 